Bangladesh J. Plant Taxon. 27(1): 79-83, 2020 (June)

(C) 2020 Bangladesh Association of Plant Taxonomists

\title{
NEW RECORDS OF SOME PHYTOPLANKTON FOR BANGLADESH: CLASS - CHLOROPHYCEAE
}

\author{
Md. Almujaddade Alfasane ${ }^{*}$ Maliha Mehnaz, Ashika Akhtar, Mst. Ayesha, \\ Md. Ataul Gani ${ }^{1}, M_{\text {ahmoud Moustafa }}^{2}, \mathrm{~S}_{\text {ally }} \mathrm{Negm}^{3}, \mathrm{Shahima} \mathrm{Islam}^{4}$ \\ AND Z.N. TAHMIDA BEgUM \\ Department of Botany, University of Dhaka, Dhaka-1000, Bangladesh
}

Key words: New records; Phytoplankton; Chlorophyceae; Bangladesh.

\begin{abstract}
The paper records 6 species of phytoplankton under the class Chlorophyceae namely, Pteromonas golenkiniana Pascher belonging to Family Phacotaceae; Pediastrum biradiatum var. biradiatum Meyen.belonging to Family Hydrodictyaceae; Scenedesmus alternas var. indicus Hortob. and Scenedesmus quadricauda var. inermis Playfair belonging to Family Scenedesmaceae; Teilingia excavata (Rafls) Bourelly and Cosmarium vexatum $\mathrm{W}$. West var. vexatum $\mathrm{W}$. West belonging to Family Desmidaceae from Sylhet Division of Bangladesh which are all new records for Bangladesh.
\end{abstract}

\section{Introduction}

Studies on phytoplanktonic members of Chlorophyceae have been made sporadically from fresh water of Sylhet Division of Bangladesh. So far, there are large number of taxonomic studied of different species of phytoplankton under Class Chlorophyceae made (Alfasane et al. 2019; Abdel-Kareem, 2009; Ahmed et al. 2008; Khondker et al. 2008; Islam and Alfasane2001a,b; 2002a,b; 2005; Islam et al. 1992; Islam 1973; Islam and Begum, 1970). The literature cited above showed that the members of the Chlorophyceae have not been studied from Sylhet Division of Bangladesh. Islam and Irfanullah 2005 have explored some of the genera of tea gardens at Srimangal. The samples were collected from different parts of Shari Goyain River, Piyain River and Madhabpur Lake of Sylhet division. But no detailed study on the class Chlorophyceae has not been done yet of these places. Therefore, the present research was undertaken to study this group of organism from fresh water habitats of Sylhet Division of Bangladesh. The present paper deals with 6 species of phytoplankton under the class Chlorophyceae which all are new records for Bangladesh. The descriptions of the organisms are given below.

\section{Materials and Methods}

The samples were collected from May 2017 to December 2019, from Shari Goyain River and Piyain River of Sylhet District and Madhabpur Lake of Moulvibazar District under Sylhet Division. The water of the sampling spots was fresh and non-polluted. The samples were collected with plankton net of mesh size $20 \mu \mathrm{m}$ and preserved in Lugol's iodine. The water temperature of these places varied from $18.8-32.5^{\circ} \mathrm{C}, 18.5-32.5^{\circ} \mathrm{C}$ and $25.0-33.0^{\circ} \mathrm{C}$, respectively and $\mathrm{pH}$ ranged from $6.9-8.5,6.9-9.8$ and $6.8-8.5$, respectively.

*Corresponding author, email: mujaddade@yahoo.com

${ }^{1}$ Department of Botany, Jagannath University, Dhaka 1100, Bangladesh

${ }^{2}$ Department of Biology, College of Science, King Khalid University, 9004, Abha, Kingdom of Saudi Arabia (KSA).

${ }^{3}$ Life Sciences Department, College of Science and literature Mahyel Aseer, King Khalid University, Abha, Saudi Arabia

${ }^{4}$ Department of Environmental Management, School of Environmental Science \& Management, Independent University, Bangladesh. 


\section{Taxonomy}

Class: Chlorophyceae; Order: Chlamydomonadales; Family: Phacotaceae ;

\section{Genus:Pteromonas Seligo}

1. Pteromonas golenkiniana Pascher

(Fig. 1)

(Huber-Pestalozzi 1961, 581, Pl. 118, Fig. 823b)

Unicellular, biflagellate, covered with a bipartile lorica. Flagella two, inserted at the anterior end through openings in the loricae. Cell length 26-29 $\mu \mathrm{m}$, breadth up to $25 \mu \mathrm{m}$, anteriorly tapered, 2 contractile vacuoles at the anterior end. Sides slightly elongated.

It is a new record for Bangladesh. Collection no. S-4(1), 05.05.2017; S-8, 13.09.2019; Shari Goyain River.

\section{Class: Chlorophyceae; Order: Sphaeropleales; Family: Hydrodictyaceae; Genus:Pediastrum Meyen}

2. Pediastrum biradiatum Meyen var. biradiatum Meyen.

(Huber-Pestalozzi 1983, 304, 307, Pl. 92, Fig. 2a-c; Pasztasleniec and Poniewozik 2004, 42, Fig. 8)

(Syn. Pediastrum lobatum Nit., P. tetrapodum Moroz.-Vodj.)

Coenobia circularin outline, with regular holes, sometimes as great as cell diameter, with 8 32 cells, individual cell 9-10 $\mu \mathrm{m}$, perforated as the sides of the cells are emarginated. The diameter of coenobium from $64.2-106.2 \mu \mathrm{m}$ (usually about $75 \mu \mathrm{m}$ ). Cell walls with developed sculpture. Marginal cells 9-25 × 10-25 $\mu \mathrm{m}$ with two lobes in the middle divided into secondary lobes each. Inner cells $x$ - shaped with diameter from 12-23 $\mu \mathrm{m}$. Only grown together with their corners. Cell wall with fine, irregular granulation.

It is a new record for Bangladesh. Collection no. P-4(3), 11.11.2017; P-8, 12.05.2019; Piyain River.

\section{Class: Chlorophyceae; Order: Sphaeropleales ; Family: Scenedesmaceae ; Genus: Scenedesmus Meyen}

3. Scenedesmus alternas var. indicus (Hortobagyi) Kirjakov

(Fig. 3) (Ling and Tyler 2000, 110, Pl. 50, Fig. 7)

Coenobia 4-8 cell, loosely 2 rows, straight with regularly alternating cells, which laterally touch each other with their proximal, rounded ends, but in 2 cell coenobias cells are almost parallel. Cells elongated, irregularly spindle-like or elongated oviform, sometimes slightly asymmetrical and curved, with wart-like thickenings at the distal ends. Cell length 7.5-11.5 $\mu \mathrm{m}$, breadth 5-8 $\mu \mathrm{m}$, ellipsoid to broadly oval.

It is a new record for Bangladesh. Collection no. M-3(4), 04.02.2018; M-15, 17.11.2019; Madhabpur Lake.

4. Scenedesmus quadricauda var. inermis Playfair

(Fig. 4) (Ling and Tyler 2000, 114, Pl. 50, Fig. 18)

Coenobia 4 cell, one row, straight with a series, which longitudinally touch each other with their proximal, rounded ends and parallel. Cells elongated, spindle-like or elongated oviform, Cell length $12-18 \mu \mathrm{m}$, breadth 3-6 $\mu \mathrm{m}$, ellipsoid to broadly oval.

It is a new record for Bangladesh. Collection no. P-3(4), 11.11.2017; P-14, 10.10.2019; Piyain River. 

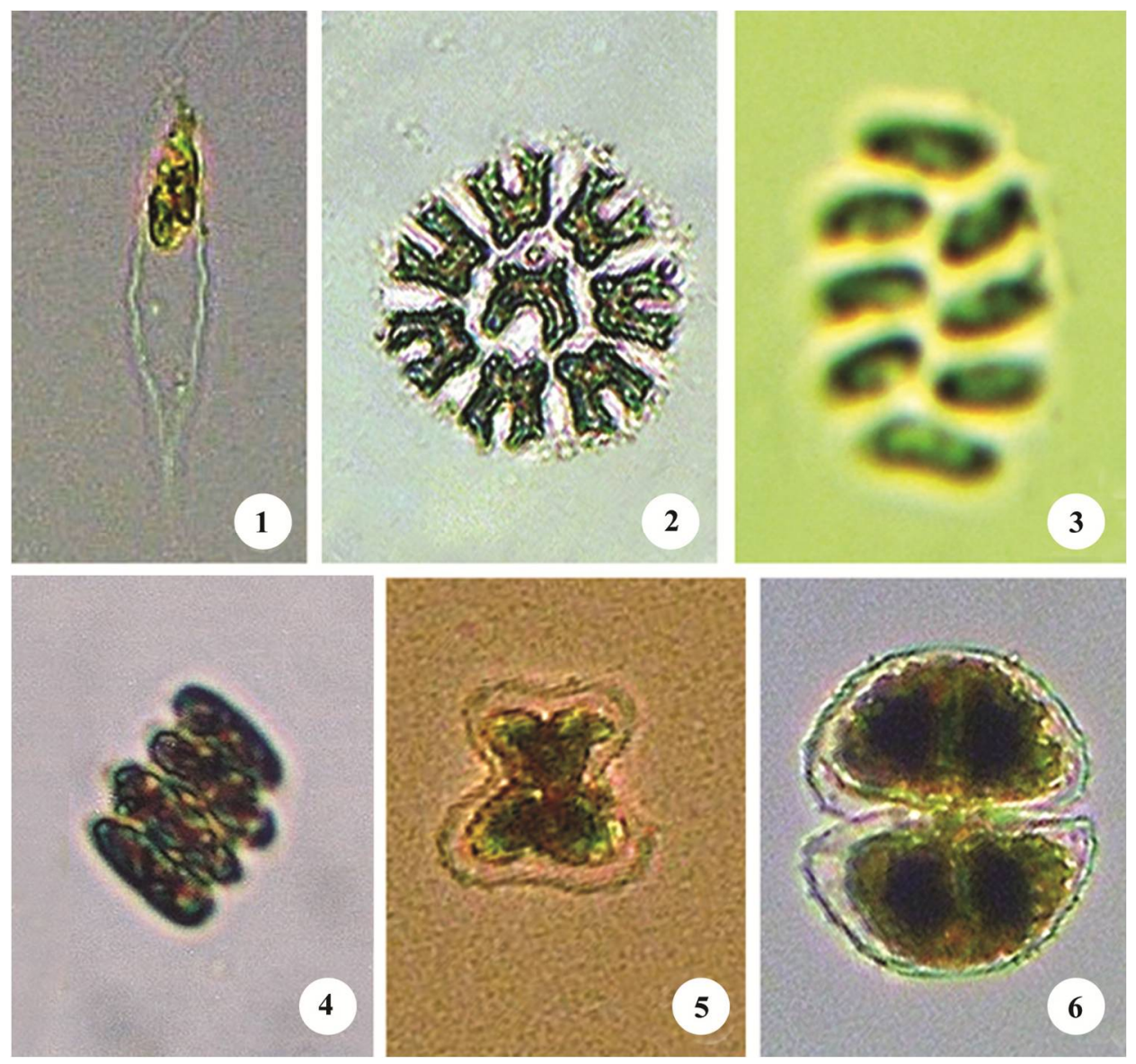

Figs 1-6: 1. Pteromonas golenkiniana Pascher, 2. Pediastrum biradiatum var. biradiatum Meyen., 3. Scenedesmus alternas var. indicus Hortob., 4. Scenedesmus quadricauda var. inermis Playfair,

5. Teilingia excavata (Rafls) Bourelly, 6. Cosmarium vexatum W. West var. vexatum W. West.

\section{Class: Chlorophyceae; Order: Zygnematales; Family: Desmidaceae;}

Genus: Teilingia Bourrelly

5. Teilingia excavata (Rafls) Bourrelly

(Fig. 5)

(Ling and Tyler 2000, 279, Pl. 151, Figs. 11-13)

Cell length 12-16 $\mu \mathrm{m}$, breadth 9-18 $\mu \mathrm{m}$, medium, about 1.1-1.2 times broader than long, deeply constricted in the middle. Semi cells elliptic- oblong with a slightly elevated.

It is a new record for Bangladesh. Collection no. S-8(4), 03.02.2018; S-17, 12.04.2019; Shari Goyain River.

\section{Genus: Cosmarium Corda 1834}

6. Cosmarium vexatum $\mathrm{W}$. West var. vexatum $\mathrm{W}$. West

(Fig. 6)

(Yamagishi and Akiyama 1995, 15: 27, Figs 1-4)

Cells medium in size, slightly longer than broad, deeply constricted in the middle, sinus narrowly linear but somewhat open at the extremity; Semicells pyramidal-trruncate, basal angles 
rounded, lateral margin convex and with six to seven undulations, apex straight or slightly undulate, intra marginal granules sparse and sub concentrically arranged gradually diminishing in size toward a smooth central area. Cell length 40-42 $\mu \mathrm{m}$, breadth 54-58 $\mu \mathrm{m}$, Isthmus $14 \mu \mathrm{m}$ broad, deeply constricted in the middle. Cell wall punctate.

It is a new record for Bangladesh. Collection no. S-5(2), 04.08.2017; S-11, 08.10.2019; Shari Goyain River.

\section{Acknowledgements}

The authors would like to extend their sincere thanks to the Deanship of Scientific Research at King Khalid University for funding this work through, Grant no. (G.R.P/150/40). It is the part of the research on preparation of bio-products from aquatic flora.

\section{References}

Abdel-Kareem, M.S. 2009. New algal records from the Arabian Gulf coast of Saudi Arabia. Bot. Res. Int, 2(4): 268-276.

Ahmed, Z.U., Begum, Z.N.T., Hassan, M.A., Khondker, M., Kabir, S.M.H., Ahmed, M., Ahmed, A.T.A., Rahman, A.K.A. and Haque, E.U. (eds.) 2008. Encyclopedia of Flora and Fauna of Bangladesh, vol. 3. Algae, Chlorophyta (Aphanochaetaceae-Zygnemataceae). Asiatic Society of Bangladesh, Dhaka. pp. 812.

Alfasane, M.A., Chowdhury, M.M.K. and Mehnaz, M. 2019. Molecular characterization and new reports of two green algae from Bangladesh. Bangladesh J. Plant Taxon. 26(1): 39-45.

Huber-Pestalozzi, G.H. 1961. Das Phytoplankton des Süßswassers. Systematik und Biologie. Teil: 5 Chlorophyceae (Grünalgen), Ordnung: Volvocales. E. Schweizerb. Verlagsb. (Nägele u. Obermiller), Stuttgart, Germany. 5: pp. 744 + pls. 157.

Huber-Pestalozzi, G.H. 1983. Das Phytoplankton des Süßswassers. Systematik und Biologie. Teil: 7.1 HälfteChlorophyceae. Schweizerb. Verlagsb. (Nägele u. Obermiller), Stuttgart, Germany. 7: 1044.

Islam, A.K.M. Nurul and Alfasane, M.A. 2001b. New records of some green planktonic algae for Bangladesh: Phacotus, Planktosphaeria and Nephrochlamys. Bangladesh J. Plant Taxon. 8(2): 51-56.

Islam, A.K.M. Nurul and Alfasane, M.A. 2005. Notes on two green plankton found in Bangladesh. Bangladesh J. Plant Taxon. 12(2): 97-99.

Islam, A.K.M. Nurul and Alfasane, M.A. 2001a. New records of some freshwater planktonic algae for Bangladesh: Species of Treubaria, Goniochloris, Tetraedriella and Tetraplektron. Bangladesh J. Bot. 30(2): 131-134.

Islam, A.K.M. Nurul and Alfasane, M.A. 2002a. New records of motile green algae for Bangladesh: Phacotus, Pteromonas and Thoracomonas. Bangladesh J. Plant Taxon. 9(1): 15-18.

Islam, A.K.M., Begum, A. and Akter, N. 1992. Study of the desmids (Chlorophyta) from Cox's Bazar, Bangladesh. Bangladesh J. Bot. 21(1): 43-51.

Islam, A.K.M.N. 1973. Freshwater algae of Bangladesh I. Chlorophyceae, Xanthophyceae and Chrysophyceae. Dacca Univ. Stud. Part B. 21(1): 69-84.

Islam, A.K.M.N. and Alfasane, M.A. 2002. New records of motile green algae for Bangladesh: Phocotus, Pteremonas and Thoracomonas. Bangladesh J. Plant Taxon. 9(1): 15-18.

Khondker, M., Alfasane, M.A. and Bhuiyan, R.A. 2008. Cylindrocystis Menegh. (Chlorophyta) : A new record for Bangladesh. Bangladesh J. Bot. 37(2): 189-191.

Islam, A.K.M. Nurul and Begum, Z.T. 1970. Studies on the phytoplankton of Dacca district. Jour. Asiatic Soc. Pak. 15(3): 227-271 + 8 pls.

Islam, A.K.M.N. and Irfanullah, H. 2005. Hydrobiological studies within the tea gardens at Srimangal, Bangladesh. III. Chlorophyceae (excluding Desmids). Bangladesh J. Plant Taxon. 12(2): 19-37. 
Ling, H.U. and Tyler, P.A. 2000. Australian Freshwater Algae (exclusive of diatoms). Bibl. Phycol. Bd. 105. J. Cramer, Berlin. pp. 643.

Pasztasleniec, A. and Poniewozik, M. 2004. Pediastrun Species (Hydrodictyaceae, Sphaeropleales) in Phytoplankton of Sumin Lake (Łęczna- Włođawa Lakeland). ActaSocietalisBotanicorumPoloniae. 73(1): 39-46.

Yamagishi, T. and Akiyama, M. 1995. (ed.) Photomicrographs of the fresh water algae.Uchida Rokakuho Pub., Tokyo, Japan. 15: pp.100.

(Manuscript received on 30 December 2019; revised on 12 April 2020) 